\title{
Emigracja polityczna z Europy Środkowej i Wschodniej. Spawozdanie z konferencji naukowej „Political Exile from Central and Eastern Europe. Motives, Strategies, Activities and Perceptions of East and West, 1945-1989", Bratysława, 19-20 XI 2013
}

\section{(c) (1) $\Theta$}

http://dx.doi.org/10.12775/KLIO.2014.039

W

zrost zainteresowania emigracją z Europy Środkowej i Wschodniej po 1989 roku jest zrozumiały. Przed upadkiem komunizmu temat ten stanowił de facto tabu, dotyczyć mógł co najwyżej emigracji wcześniejszych, z okresu przed II wojną światową, w praktyce zaś - emigracji XIX-wiecznej. Odtwarzanie zapomnianych, nieznanych, wypartych historii okazuje się zatem istotnym elementem budowania wiedzy o poszczególnych społeczeństwach, przy czym - co szczególnie ważne w kontekście globalizującego się świata - od razu sytuuje tematykę narodową w szerszym kontekście powiązań międzynarodowych, zwłaszcza zaś - przynajmniej z naszej perspektywy - ogólnoeuropejskich i euro-amerykańskich. W przypadku Europy Środkowej i Wschodniej w okresie po II wojnie światowej kluczowym czynnikiem wpływającym w istotny sposób na lokalne opowieści o emigracji jest komunizm, szerzej zaś - zimnowojenny podział świata. Współczesny zwrot w kierunku emigrantologii pokrywa się również ze zmianami zachodzącymi w humanistyce i naukach społecznych, albowiem badania prowadzone nad emigracją mają charakter transdyscyplinarny, prowadzone są wyjściowo przez takie dyscypliny, jak: historia, literaturoznawstwo, socjologia, antropologia, politologia, stosunki międzynarodowe, prawo, ekonomia itd. Rzeczywiste badania mają często charakter łączący poszczególne nauki, będąc przykładem nowoczesnej dyscypliny-parasola, w której ważniejsza jest problematyka emigracyjna niźli dyscyplinarna czystość i ortodoksja.

Wszystkie powyższe uwagi można odnieść do odbywającej się w dniach 19-20 listopada 2013 roku w Bratysławie na Słowacji konferencji pt. Political Exile from Central and Eastern Europe. Motives, Strategies, Activities and Perceptions of East and West, 1945-1989 [Emigracja polityczna 
z Europy Środkowej i Wschodniej. Motywy, strategie, dziatalnośc i postrzeganie Wschodu i Zachodu, 1945-1989]*. Konferencja została zorganizowana przez Ústav pamäti národa (Instytut Pamięci Narodowej) we współpracy z European Network Rememberance and Solidarity (Europejska Sieć Pamięć i Solidarność, Warszawa), finansowana zaś była przez rząd federalny Niemiec. Współorganizatorami konferencji były: polski Instytut Pamięci Narodowej, słoweński Študijski center za narodno spravo, Deutsche Gesellschaft für Osteuropakunde i Ambasada Rzeczpospolitej Polskiej w Bratysławie. Konferencja zgromadziła około czterdziestu osób prezentujących wystąpienia, prowadzących sesje, komentujących referaty, biorących udział w dyskusjach plenarnych, a także liczne grono słuchaczy, dyskutantów itd. Wśród nich znaleźli się przedstawiciele Niemiec, Polski, Ukrainy, Czech, Słowacji, Węgier, Rumunii, Słowenii, Chorwacji, Macedonii, a także Stanów Zjednoczonych, Kanady, Francji i Włoch. Szczególnie ważne w wypadku tej konferencji było połączenie badaczy - często młodego pokolenia - ze świadkami - politycznymi emigrantami z Europy Środkowej i Wschodniej, a także - jak w przypadku np. A. Rossa Johnsona - łączenia dwóch ról: naukowca-historyka i świadka epoki, w tym wypadku osoby związanej z Radiem Wolna Europa, następnie zaś historyka opisującego dzieje tej instytucji. Ta podwójna optyka - świadka i badacza - nadała konferencji szczególny charakter.

Konferencja została podzielona na sześć paneli tematycznych i okrągły stół - rozmowę ze świadkami. Pierwszy panel pt. „Waves and Motives of Political Exile" składał się z trzech wystąpień plenarnych, prowadzony był zaś przez Ondreja Podolca, dyrektora ds. badań w słowackim Instytucie Pamięci Narodowej, wykładowcę Uniwersytetu Komeńskiego w Bratysławie. Wspomniany A. Ross Johnson przedstawił referat pt. "The Media Activities from East European Political Emigrants through US Perspective". Badacz, wcześniej związany z Radiem Wolna Europa, wciąż zajmujący się dokumentowaniem działalności stacji**, przedstawił znaczenie radia dla historii emigracji z Europy Środkowej i Wschodniej, jak również rolę amerykańskich służb specjalnych w rozwoju stacji. Otrzymaliśmy zatem nie tylko spojrzenie z punktu widzenia emigrantów, ani nawet z perspektywy krajowej, lecz zewnętrznej - w tym wypadku amerykańskiej. Z kolei Sławomir Łukasiewicz w referacie „Cold War Central and Eastern 
European Émigrés - Main Waves and Dominant Motives” zarysował szeroki kontekst środkowo- i wschodnioeuropejskiej emigracji po II wojnie światowej, pokazując zarazem wspólne cechy przedstawicieli poszczególnych krajów i narodów, jak i istotne elementy różniące ich między sobą. Swoją klasyfikację oparł na następujących cechach wyróżniających: momencie historycznym i przyczynach opuszczenia kraju, uwarunkowaniach jej funkcjonowania za granicą i relacjach z krajem, liczebności, politycznym zaangażowaniu i światopoglądowym uwikłaniu, środowisku, wsparciu (bądź nie) w kraju zamieszkania, podkreślając, że zbyt często używa się zbiorczego, upraszczającego określenia emigracja z Europy Środkowej czy Wschodniej, podczas gdy poszczególne emigracje widzieć należy w całej ich złożoności. Przy czym zakres geograficzny, do którego odwoływał się Łukasiewicz obejmował kraje od Finlandii na północy po Grecję na południu. Również Róbert Letz w referacie Slovak Political Exile in Czechoslovak and European Context zwracał uwagę na wielość emigracji oraz emigracyjnych pozycji i postaw, chociaż skupiał swoją uwagę na przypadku czeskim i - zwłaszcza - słowackim. Nawet w tak wykrojonym polu zainteresowań liczba fal, kierunków, podziałów, ugrupowań, itd. jest niezwykle duża, a wyłaniający się z tego obraz jest niesłychanie złożony. Przypadek Słowacji jest tu szczególny, jeśli pod uwagę weźmiemy historię II wojny światowej i faszystowskiego zaangażowania tego państwa (i emigracji 1945 roku), następnie zaś dojścia komunistów do władzy (antykomunistyczna emigracja 1948 roku), podziału na tych, którzy dążyli do niezależnej i niepodległej Słowacji oraz na tych, którzy chcieli trwać w sojuszu z Czechami itd. Dyskusja, która nastąpiła po tych trzech wystąpieniach tylko ten obraz złożoności emigracyjnej historii pogłębiła, antycypując niejako dalszy ciąg konferencji.

Panel drugi pt. Ideas and Political Concepts in Exile moderowany był przez Heike Dörrenbächer. Peter Jašek - faktyczny organizator konfe-

* Udział w konferencji, a zatem i powstanie niniejszego tekstu było możliwe dzięki projektowi Pracownia Badań nad Pamięcią Zbiorową w Postkomunistycznej Europie (POSTCOMER) realizowanemu na Wydziale Filologicznym Uniwersytetu Mikołaja Kopernika w Toruniu. Projekt został sfinansowany ze środków Narodowego Centrum Nauki przyznanych na podstawie decyzji nr 2011/03/D/HS2/06170. 
rencji i jej sekretarz - przedstawil referat pt. Activities of the Slovak World Congress in the Years 1970-1989. Skupił się w nim na historii Światowego Kongresu Słowaków - organizacji parasolowej dla emigracji słowackiej pokazując wyraźnie, jakie napięcia i podziały towarzyszyły jej powstaniu i funkcjonowaniu. Zarazem zwrócił uwagę na niezwykle istotny fakt, który nie ogranicza się tylko do przypadku słowackiego, a który wciąż jest słabo zbadany, tzn. określenie, jaką rolę w tych podziałach i animozjach na emigracji odgrywały służby specjalne państw, z których pochodzili emigranci (w tym wypadku - komunistycznej Czechosłowacji). Faktyczna ich rola w funkcjonowaniu emigracji rzeczywiście wymaga opisania, a jej komparatystyczne ujęcie odnoszące się do emigracji z całej Europy Środkowej i Wschodniej jest niesłychanie ważne. Z kolei Milena Przybysz przedstawiła referat pt. „Jerzy Giedroyć, the Environment of Parisian "Kultura” and the Conceptions about the Role of Roman Catholic Church in Poland under Communism”, który zgodnie z tytułem koncentrował się na problematyce religii i Kościoła na łamach „Kultury”, w twórczości samego Giedroycia zwłaszcza, wskazując na fakt, że kwestia ta różniła redaktora z Maisons-Laffitte od większości polskiej emigracji. Mateja Čoh Kladnik ze Słowenii w referacie pt. „Slovene Emigration in Austria as Part of Struggle against Communist Regime in Slovenia 1945-1949” skupiła się na krótkim okresie powojennym w dziejach jugosłowiańskiej (przede wszystkim słoweńskiej i serbskiej) emigracji, zwłaszcza w Austrii i Włoszech, które dążyły do obalenia komunizmu. Podobnej tematyki dotyczył referat Mišo Dokmanović pt. „National Statehood as the Primary Goal of the Macedonian Political Emigration: The Case of Liberation Committee of Macedonia”, w którym autor omawiał kwestię macedońskiej emigracji, również w kontekście Bułgarii i Grecji. Każdy panel kończyła wypowiedź zaproszonego gościa, który podsumowywał wszystkie referaty, otwierał pole do dyskusji, niekiedy rozwijał wybrane wątki. W przypadku tego panelu był to Jakub Tyszkiewicz, który zwrócił uwagę na wspólną dla tych

** A. R. Johnson, Radio Free Europe and Radio Liberty: The CIA Years and Beyond, Stanford University Press 2010; Cold War Broadcasting: Impact on the Soviet Union and Eastern Europe: A Collection of Studies and Documents, ed. A. R. Johnson, E. R. Parta, CEU Press 2012. 
referatów (może z wyjątkiem wystąpienia Mileny Przybysz) problematykę międzynarodowej rozpoznawalności wspomnianych narodów (słowackiego w ramach państwa czechosłowackiego; słoweńskiego i macedońskiego w ramach Jugosławii). Tyszkiewicz pokazał również, że kwestia walki o niepodległość (np. wobec komunistycznej władzy) była charakterystyczna dla większości emigracji z tej części Europy, krótko opisując przykład polskiej walki antykomunistycznej.

Panel trzeci pt. „Relations between the Exile Organisations” moderowany był przez Burkharta Olschowskiego z Europejskiej Sieci Pamięć i Solidarność. Filip-Lucian Iorga z Rumunii przedstawił niezwykle ciekawą perspektywę - klasową - dotyczącą rumuńskiej arystokracji na emigracji w referacie pt. „The Descendants of the Romanian Nobility Facing Repression and Exile during the Communist Regime". Referat jest częścią większej całości - projektu „The Memory of the Romanian Elites”. Z kolei piszący te słowa wygłosił referat pt. „Always in Minority. Polish Left-wing Exile Intellectuals against Communism and Emigrants Majority”, w którym przedstawił historię Manfreda Kridla, Józefa Wittlina i innych polskich emigrantów intelektualistów w Stanach Zjednoczonych w latach czterdziestych XX wieku, którzy, próbując zachować własne przekonania polityczne lewicowe (czy liberalno-lewicowe, socjaldemokratyczne), zarazem byli zdecydowanymi przeciwnikami komunizmu, o wspieranie którego byli często oskarżani. Andrzej Mietkowski - także de facto w podwójnej roli, świadka i badacza - przedstawił autobiograficzne wystąpienie pt. „My Own Exile” (chociaż pierwotnie miało nosić tytuł „Reflection about the Polish Exile”). Opisywał polską emigrację w Paryżu lat osiemdziesiątych, zwracając uwagę na istotne kwestie terminologiczne w odniesieniu do własnej pozycji. Zastanawiał się, czy zasadne jest używanie terminu emigrants (emigranci), czy raczej nie powinniśmy mówić o refugees (uchodźcy) i exiles (emigracja jako zesłanie czy wygnanie). Chociaż konferencja w tytule używała pojęcia exile, to jednak w referatach nad wyraz często - i zapewne w sposób do końca nieuświadomiony - pojawiało się określenie emigration. Natomiast Bernd Florath wskazał na często zapominaną i z wielu powodów specyficzną perspektywę wschodnioniemiecką w kwestii emigracji, prezentując referat pt. German Special Case of Emigration. Specyfika tej sytuacji polegała oczywiście na tym, że niektórzy emigranci, uciekając przed wschodnioniemiec- 
kim komunizmem, trafiali do RFN, pozostając zatem w obrębie państwa niemieckiego. Skrajnym przykładem tej specyfiki, choć często w praktyce się zdarzającym, była emigracja polityczna, która odbywała się w obrębie jednego miasta - Berlina. Z głosem podsumowującym wystąpił Raphael Krüger z Niemiec, który odniósł się bezpośrednio do wszystkich referatów. Zwrócił uwagę na niejednoznaczności, ambiwalencję, która w owych referatach w odniesieniu do rzeczywistości emigracyjnej się pojawiała: podział na prawicę-lewicę (i miejsce socjaldemokracji w tym binarnym obrazie rzeczywistości politycznej), zwłaszcza gdy weźmiemy pod uwagę tradycje lokalne (np. polska), historycznie zakorzenione w rzeczywistości międzywojennej, szerzej - kontekst europejski, a następnie jego przeniesienie do odmiennej tradycji politycznej, np. Stanów Zjednoczonych. Zatem kwestie terminologiczne, przedstawione przez Mietkowskiego, znalazły tu rozwinięcie.

Dzień pierwszy zakończył „okragły stół” z udziałem świadków, prowadzony przez Mateja Medveckiego. Uczestniczyli w nim Włodek Goldkorn z Włoch, František Mikloško ze Słowacji oraz Dušan Tóth ze Słowacji/ Kanady. Goldkorn wyjechał z Polski w 1968 roku na fali wystąień antysemickich. Przez krótki czas przebywał w Izraelu, podobnie jak np. Zygmunt Bauman, chcąc jednak zachować swoje lewicowe przekonania, nie mógł pogodzić się z polityką tego państwa i, podobnie jak wspomniany socjolog, postanowił wyjechać i zamieszkał we Włoszech. Po 1989 roku nie wrócił do Polski, albowiem z Włochami związał swoje życie prywatne i zawodowe. Tóth również wyjechał w 1968 roku, wspóttworzył Światowy Kongres Słowaków, którego był sekretarzem, lecz postanowił wrócić w 1989 roku do Czechosłowacji (de facto na Słowację). Ten powrót okazał się bolesny, albowiem państwo doby transformacji ustrojowo-gospodarczej nie spełniło pokładanych w nim nadziei. Z kolei Mikloško mówił m.in. o roli Kościoła (także tego ukrytego, podziemnego) w kraju w czasie rządów komunistów. Ten wątek został też podjęty przez Tótha i znaczna część dyskusji, która się wówczas wywiązała, dotyczyła znaczenia Kościoła w podtrzymywaniu słowackości. Wspólnym wątkiem tych trzech głosów a także dyskutantów z sali była kwestia relacji pomiędzy emigracją polityczną z czasów komunistycznych a realiami poszczególnych państw po 1989 roku.

Drugi dzień konferencji rozpoczął się od czwartego panelu pt. „Information Channels and Support for the Anti-Communist Opposition 
in Home Countries" moderowanego przez Tomáša Kluberta ze Słowacji. Pavol Holeštiak zaprezentował referat pt. „Slovak Media Abroad in Exile”, przy czym w czasie wystąpienia zdążył de facto omówić poszczególne fale słowackiej emigracji, na tytułową kwestię mediów emigracyjnych nie starczyło już czasu. Z kolei Prokop Tomek z Czech mówił o Radiu Wolna Europa w wystąpieniu zatytułowanym "Reflexion of the Broadcasting of Radio Free Europe". W interesujący sposób skupił się na słabo zbadanym aspekcie funkcjonowania rozgłośni, tzn. na kwestii odbioru radia przez słuchaczy, reakcji zwrotnej, niemożności kontaktu ze słuchaczami zza żelaznej kurtyny, wskazując wszakże, że pomimo formalnych ograniczeń, z biegam lat, zwłaszcza zaś w latach osiemdziesiątych, za pomocą listów, telefonów, kontaktów bezpośrednich, udawało się tę łączność nawiązać i podtrzymywać. W tak zarysowanym temacie nie mogło zabraknąć oczywiście również wątków dotyczących roli służb specjalnych, represji spotykających osoby słuchające Radia w kraju itd. A. Ross Johnson od razu dopowiedział, że rzeczywiście, możliwa do zaobserwowania w tej kwestii jest dynamika historyczna, przy czym twierdził, że o ile lata pięćdziesiąte stanowiły absolutny brak kontaktu Radia ze słuchaczami, o tyle od lat sześćdziesiątych sytuacja zaczęła się poprawiać, przesuwając zatem cezurę wyznaczoną przez Tomka. Z kolei Jan Cholínský przedstawił referat pt. "National Democrat Rudolf Kopecký - Central Person of the Czech Nonsocialist Exile Journalism and Ideological Counterpart of the Director of the Czechoslovak Desk at RFE Ferdinand Peroutka”. Zgodnie z tytułem, głównym bohaterem wystąpienia był dziennikarz i centro-prawicowy czeski polityk emigracyjny Rudolf Kopecký, który został przedstawiony w zestawieniu z reprezentującym lewą stronę sceny politycznej Ferdinadem Peroutką z Radia Wolna Europa. Referent zwracał uwagę, że grupa prawicowej emigracji czeskiej jest - po pierwsze - niezbadana i słabo wciąż znana, a po drugie - zdecydowanie niedoceniana. Referat był niestety zbyt chaotyczny, wiele interesujących kwestii zostało jedynie zasygnalizowane, wymagają więc rozwinięcia. Alexandar Jakir z Chorwacji opatrzył panel komentarzem , zwracając uwagę, że przynajmniej część z prezentowanych referatów zupełnie pominęła kontekst kulturowo-historyczny i polityczno-społeczny, tak przecież dla wszystkich emigracji ważny. W dyskusji kwestia ta była rozwijana. Zwracano bowiem uwagę na to, że nasza wiedza o emigracji wciąż daleka jest od etapu do- 
brego syntezowania, skupiając się na pracy u podstaw, przede wszystkim w archiwach, ale także w rozmowach ze świadkami itd. Na dobre, pełne, wieloaspektowe opracowanie problematyki emigracyjnej przyjdzie nam zatem jeszcze poczekać, zwłaszcza gdy myślimy o syntezie obejmującej całą Europę Środkową i Wschodnią. Dotychczasowe prace o przeglądowym charakterze są w tej optyce mocno niepełne, zazwyczaj skupiają się na postaciach i środowiskach najbardziej znanych.

Z kolei panel piąty pod tytułem „Responses and Perceptions on Political Exile" moderowany był przez Petra Jaška. Pierwsze wystąpienie Beatrice Scutaru nosiło tytu ,'Romania, enemy of its own people!' Romanian Exile Groups' Role in Changing the View of Romania in France and Western Europe during the 1980s”. Autorka pokazała proces zmiany, która dzięki emigracji rumuńskiej zaszła w społeczeństwie francuskim, zwłaszcza wśród intelektualistów. Otóż jeszcze w latach siedemdziesiątych i na początku lat osiemdziesiątych wizerunek Nicolae Ceauşescu we Francji był neutralny albo nawet pozytywny. Za sprawą rumuńskiej emigracji i jej walki o prawa człowieka, wizerunek ten w latach osiemdziesiątych zaczął się zmieniać na negatywny. Anna Siwik wygłosiła referat „Ideological Dilemmas of Polish Socialists 1945-1989”, przedstawiając emigracyjną historię Polskiej Partii Socjalistycznej, która pozostała socjalistyczna w warstwie przekonań, lecz zarazem prodemokratyczna, sprzeciwiając się integracji PPS w kraju z PPR i jednowładztwa PZPR. Z kolei Bernd Robionek z Niemiec przedstawił temat: „Outsiders of the Cold War? Changing Attitudes towards Communism within the Croatian Political Emigration towards Anti-Communism" (pierwotnie referat dopełniały daty 1945-1980), wskazując na trzy fale tamtejszej emigracji: 1) powojenną, która skupiła się przede wszystkim we Włoszech i Austrii, chociaż najbardziej znane są przykłady osób związanych z władzami faszystowskiego Niezależnego Państwa Chorwackiego z czasów II wojny światowej - jak Ante Pavelicia - którzy uciekli np. do Argentyny; 2) drugą, od połowy lat pięćdziesiątych do połowy lat sześćdziesiątych. Była to emigracja przede wszystkim ekonomiczna, a 3) trzecia, po wiośnie 1971 roku, miała charakter polityczny. Dalej autor omawiał charakter poszczególnych fal emigracyjnych i ich wzajemne oddziaływanie, a także ich aktywność polityczną, w tym m.in. akty przemocy i terroru mające służyć rozwiązywaniu konfliktów politycznych, których autorami byli przedsta- 
wiciele chorwackiej emigracji. Yevgen Rogovy z Ukrainy wygłosił referat pt. „Political Activities of the Ukrainian Political Exile in the West in the Second Half of $20^{\text {th }}$ Century", opisując historię antysowieckiej i antystalinowskiej emigracji ukraińskiej dążącej do powołania wolnej i niepodległej Ukrainy. Komentarz do referatów przedstawił Filip-Lucian Iorga, a szczególnie ożywioną dyskusję wywołał referat Robionka, głos w kwestii chorwackiego terroryzmu emigracyjnego zabrali m.in. Johnson i Jakir.

Ostatni, szósty panel, nosił tytuł „Political Exile and Role of the Secret Services" i moderowany był przez Michala Mikloviča. Richard Cummings, również świadek - pracujący w Radiu Wolna Europa - w wystąpieniu pt. "Fighting the Big Lie with the Big Truth" omówił kwestię finansowania Radia Wolna Europa przez Stany Zjednoczone, m.in. sposobów pozyskiwania funduszy na ten cel. Zsuzsanna Borvendég wygłosiła referat pt. "Target on the Horizon. The Hungarian State Security and the Political Emigration”. Prelegentka dotknęła kwestii już wcześniej poruszanej na konferencji, tzn. infiltracji przez tajne służby węgierskich środowisk emigracyjnych. Szczególnie warte podkreślenia jest to, że służby nie tylko chciały pozyskiwać współpracowników i informacje na temat działalności emigracji, ale stawiały sobie poważniejszy cel - wpływanie na linię polityczną tych środowisk. Podobne wątki rozwijał także Alexandar Jakir, przedstawiając referat pt. "Political Emigration from Croatia and the Role of the Yugoslav Secret Service”. Autor skupił uwagę na działalności służb specjalnych podejmowanych w stosunku do chorwackiej emigracji antykomunistycznej. W tym wypadku służby nie ograniczały się do inwigilacji, ani inspiracji, lecz posuwały się dalej - do zabójstw politycznych. Zdaniem Jakira służby specjalne Jugosławii zabiły w czasie zimnej wojny więcej osób na emigracji niż służby państw boku wschodniego. W ostatnim referacie pt. „Cain Syndrome: Ukrainin Nacionalist Exile in the after War Germany through the View of CIA 1945-1959” omówiono m.in. działalność banderowców w Monachium w okresie powojennym, w tym zabójstwo Stepana Bandery wykonane przez KGB na podstawie rozkazu Nikity Chruszczowa. Zamykający komentarz do tej sesji przedstawił Matej Medvecký.

Podsumowując, należy wskazać na kilka wniosków płynących z referatów i dyskusji konferencyjnych. Po pierwsze, trudno jest mówić o jednej emigracji politycznej z Europy Środkowej i Wschodniej a nawet z poszcze- 
gólnych państw. Każda emigracja jest zjawiskiem niejednorodnym, złożonym, wieloaspektowym, wielowymiarowym itd. Po drugie, konferencja dowiodła, jak wielu aspektów historii emigracyjnej wciąż jeszcze nie znamy, jak nasza wiedza na ten temat jest niepełna, natomiast wciąż prowadzone badania odsłaniają dopiero część wypartego dziedzictwa, zapomnianej tradycji. Po trzecie, zauważono, że pewne wątki, pojawiające się we wszystkich opowieściach, wciąż są słabo rozpoznane, mogą zaś okazać się dla tej historii kluczowe, jak np. rola tajnych służb w funkcjonowaniu środowisk emigracyjnych. Po czwarte, powyższe czynniki sprawiaja, że daleko nam do przedstawienia pełnej, porównawczej historii emigracji z Europy Środkowej i Wschodniej. Organizatorom należy podziękować za zaproszenie uczestników konferencji z całej Europy Środkowej i Wschodniej (chociaż wyraźnie odczuwalny był brak przedstawicieli np. Rosji czy państw nadbałtyckich), uczestnikom za odkrywanie - często na podstawie żmudnych badań archiwalnych w instytucjach krajowych i zagranicznych - zapomnianych bądź w ogóle nieznanych kart wspólnej historii. 